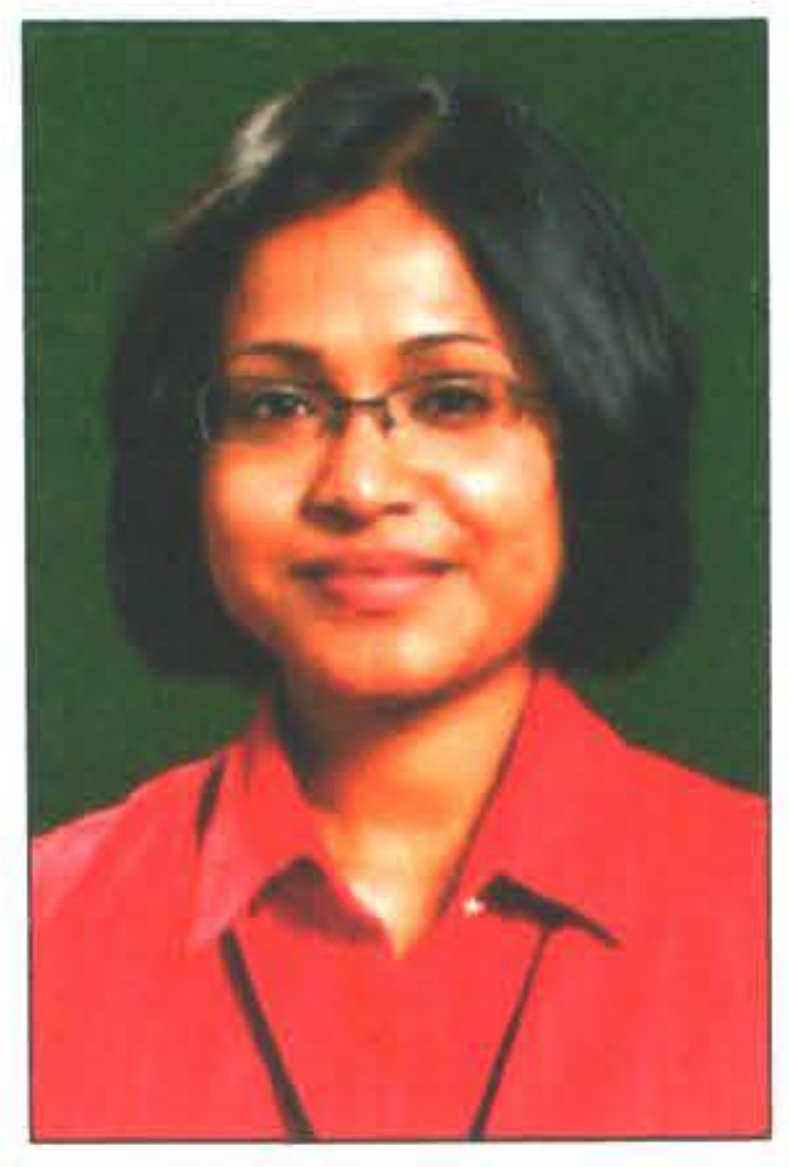

\title{
LABOUR MARKET \\ ADJUSTMENT IN THE CONSTRUCTION INDUSTRY \\ 2001-2006
}

\author{
Menaka Saravanaperumal
}

Work Knowledge and Skills

Statistics New Zealand, Wellington

\begin{abstract}
The construction industry experienced heightened activity from 2001 to 2006 concurrent with low interest rates, high population growth, strong wage and job growth, and property investments from overseas. Following this heightened demand, there was a 41.4 percent increase in employment in the construction industry over the six-year period. This compared with a 15.5 percent increase across all other industries excluding construction. This study, uses the Linked Employer-Employee Data (LEED) to investigate how the market adjusted to the higher level of employment.
\end{abstract}

Across the construction industry from 2001 to 2006, relative average wage growth was subdued. However, a change in the composition of labour hired was evident. The majority of inflows into the construction industry came from alternative industries, with every six in ten workers previously engaged in an alternative industry in the past year. The construction industry continued to source its workers from the same industries. However, the composition of workers flowing from these industries into construction shifted towards younger and hence, less experienced workers. This shift suggests that there were concessions on quality in adjusting to the higher level of employment.

The increased inflow of younger and less experienced individuals, together with the relatively higher inflow of selfemployed individuals into the construction industry, explains the comparatively subdued growth in average wages across the construction industry at a time of strong employment growth.

\section{Introduction}

The construction industry experienced heightened activity from 2001 to 2006 concurrent with low interest rates, high population growth, strong wage and job growth, and property investments from overseas.' Following the heightened demand for construction services, there was a related increase in employment. The number of individuals receiving wages and salaries or self-employment income as their main income source in the construction industry increased by 41.4 percent over the 2001-2006 period, compared with 15.5 percent across all industries excluding construction. ${ }^{2}$ This study investigates how the market adjusted to the higher level of employment.

Across the construction industry as a whole, the relative average wage growth was subdued. A change in the composition of hired workers was evident. There was increased reliance on inflows from those out of the workforce, who came mainly from the 35 years and over age group. There was also a reduced reliance on former benefit recipients. This was likely due to the smaller number of people receiving benefit during this period and hence, fewer people that can be drawn on for employment in the construction industry. The positive human capital effects from hiring relatively older workers and fewer former benefit recipients appears to have been offset by the increased inflow of younger workers from other industries.

The majority of inflows into the construction industry came from alternative industries, with every six in ten workers previously engaged in an alternative industry in the past year. The construction industry continued to source its workers from the same industries. However, the composition of workers flowing from these industries into construction shifted towards younger and hence, less experienced workers. This shift suggests that there were concessions on quality in adjusting to the higher level of employment.

The construction industry also saw an increased inflow of self-employed individuals over the 2001-2006 years. The increased entry of self-employed individuals, together with the increased employment of younger and less experienced individuals, was expected to have reduced the wage pressures on the industry as a whole at a time of strong employment growth. 
A number of datasets, including Statistics New Zealand's Linked Employer-Employee Data (LEED), were used to gain an understanding of the labour market adjustments at play. In addition to understanding how the labour market adjusted to the higher level of employment, another intended outcome of this analysis is an increased insight into LEED and its potential.

The analysis is covered in six sections. The first section describes the datasets used in the analysis. Section two provides an industry overview. The third section looks at changes in the level of employment. Adjustment mechanisms that led to the increased level of employment are discussed in the fourth section. The fifth section concludes. The final section considers future research.

\section{Data}

Statistics New Zealand's Linked Employer-Employee Data (LEED) was a key dataset in this analysis. LEED is produced by combining Inland Revenue (IRD) data on individual incomes where tax is deducted at source, from Employer Monthly Schedules (EMS), and business data from Statistics New Zealand's Business Frame (BF).

EMSs are submitted by all organisations registered with IRD who have employees receiving earnings from which $\operatorname{tax}$ is deducted at source. The EMS outlines all the employees working for the filing employer during a particular month and provides details on the amount paid to employees, the amount of tax deducted at source during a particular month, and some job start and end dates.

The BF is a database of private and public sector businesses engaged in the production of goods and services in New Zealand. Information from the BF includes the industry and sector the business belongs to, the number of geographical units (physical locations), the count of employees at each geographical unit, and the ownership structure of the business.

The link between the two data sources is the employer IRD number, a unique identifier usually common to both data sources. The IRD number of a business entity is associated with an enterprise unit on the BF. This enterprise in turn is linked to one or more geographical units. Employees linked to their employers via the EMS can also be linked to an enterprise and geographical unit on the BF. These links between employers and employees and between enterprises and geographical units can be followed over time and provide valuable information on the dynamics of the labour market.

One key weakness of LEED is the absence of information on hours worked. Given this, it is not possible to identify if low monthly earnings are the result of fewer hours worked, or if it is due to lower pay. Likewise, higher earnings could be a factor of longer hours worked and/or higher pay rates. Dave Maré and Dean Hyslop (2006) have attempted to adjust for this deficiency. ${ }^{3}$ Another weakness of LEED is the limited data on employee characteristics, such as qualification and occupation. Presently, employee characteristics are limited to sex and age.

The Quarterly Employment Survey (QES) and the Labour Cost Index (LCI) are also used in this study to complement LEED earnings measures and to obtain information on hours paid, which is a close approximation for hours worked.

\section{Industry overview}

Using the 1996 Australian and New Zealand Standard Industrial Classification (ANZSIC96), the construction industry is classified into general construction, and construction and trade services. This study includes all 21 subclasses within the broader 'General construction' and 'Construction trade services' groups in ANZSIC $96 .{ }^{4}$ Building of houses, apartments, factories, offices, schools, roads, bridges, modifications and additions to existing structures, maintenance, repairs and improvements, fall within the domain of the construction industry as classified by ANZSIC 96 .

The industry had an annual gross output of approximately $\$ 7.8$ billion $^{5}$ and employed 173,200 individuals during the March 2006 year $^{6}$. This contributed 5.2 percent towards total GDP and 7.8

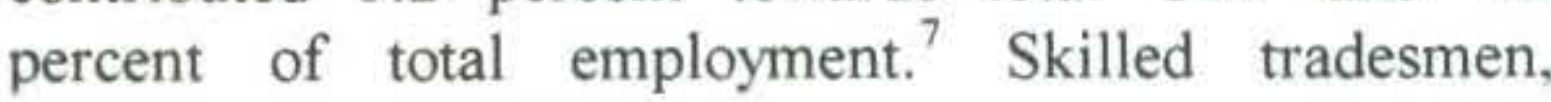
labourers, machine operators, managers and administrative personnel made up the total employed.

Entry into the industry has traditionally been through formal apprenticeship of varying duration depending on the trade; or informal acquisition of skills on the job. Self-regulation within the industry through trade organisations like the Certified Registered Builders and Registered Master Builders and registering requirements for plumbers, electrical workers and chartered engineers, has emphasised formal qualifcation and promoted entry through formal qualifications. Despite this, a study by the Department of Building and Housing in $2005^{8}$ suggested there was a low level of vocational qualification in the industry and increased reliance on informal and unsystematic training. ${ }^{9}$

Qualifications specifically developed for the building and construction industry are administered by the Building and Construction Industry Training Organisation (BCITO). The mediation of wages is outside the scope of BCITO. Instead, wages are agreed on at an individual level with the employer. The New Zealand Building and Trade Union (NZBTU) also negotiates pay and working conditions on behalf of its members. However, the union membership rate in the construction and trade services industry is less than 2 percent. $^{10}$ The employers in the industry constitute self-employed, partnerships, and 
private and public companies. The demand for construction workers stem from these employers.

\section{Employment}

The level of employment is determined by the interaction of supply and demand, where the supply of construction workers is defined as individuals who are willing and able to work in the construction industry. The demand for labour is typically referred to as a derived demand, that is, firms demand labour according to the demand for their output. Hence, the demand for construction workers is derived from the demand for building and trade activities. Given the employment of qualified and unqualified individuals, the demand for construction workers refers to those who are able to perform construction-related jobs as opposed to those with construction-related qualifications.

Changes in demand for labour can be influenced by changes in the volume of demand for industry output; changes in labour/capital productivity; changes in production technology; and/or substitution between labour and capital. The change in demand for construction workers over the 2001-2006 period was largely caused by the rapid rise in demand for building and trades activities.

The demand for building and trade activities boomed over the 2001-2006 period. The value of construction work as measured by the issuance of building consents increased by 78.7 percent over the six years (2001-2006) as seen in figure 1 .

Figure 1:

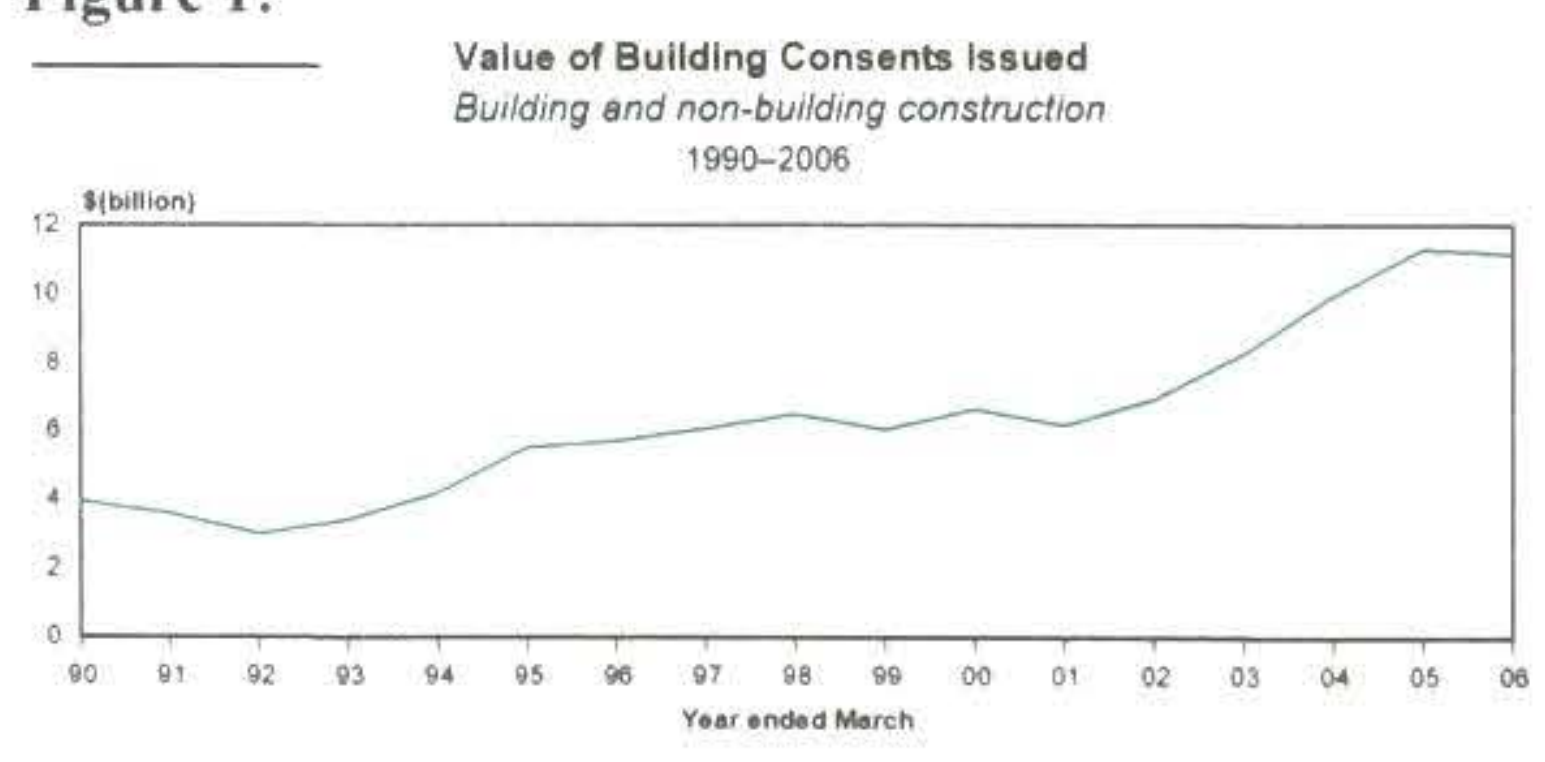

Source: Statistics New Zealand, Building Consents Issued

Many independent factors contributed to the construction boom, including low interest rates from early 2001 to early 2004, high population growth driven by increased migration, strong wage and job growth, and property investments from overseas. ${ }^{11}$

There was a related increase in employment in the construction industry. The number of individuals receiving wages and salaries and self-employment income in the construction industry increased by 41.1 percent, from 122,470 in 2001 to 173,200 in $2006 .^{12}$ This compares with a growth in employment of 15.5 percent across all industries excluding construction. Over this period, the share of individuals receiving wages and salaries or self-employment income in the construction industry relative to all other industries increased from 6.6 percent in 2001 to 7.8 percent in 2006.

Insight into how the market adjusted to the higher level of employment is the key focus of this paper and is considered next.

\section{Adjustment to a higher level of employment}

\section{Price of labour as an adjustment tool}

The price paid for labour (wages and salaries) is the equilibrating tool in a simple labour market model where in the event of a shortage or excess demand, wages should be negotiated upwards, which in turn attracts new entrants into the industry. ${ }^{13}$ The simple labour market model is based on the assumptions of perfect competition, profit maximisation and homogeneity of workers.

In reality workers can be of varying types. They can be variable in the human capital they possess, where human capital is defined to be the stock of knowledge, skills, aptitudes, education and training. The human capital theory accounts for the heterogeneity of workers.

Under the simple labour market model and the human capital view of the labour market, wages paid is a product of the productivity of the workers. However, under the latter model the productivity of the workers can vary in relation to their stock of human capital. Hence, wages paid can vary in relation to their stock of human capital.

Three datasets were used to investigate the responsiveness of wages in the construction industry during the period of heightened demand. These include LEED, the Quarterly Employment Survey (QES) and the Labour Cost Index (LCI). All three datasets are based on the ANZSIC96; hence, the scope of the construction industry is consistent across all three datasets. However, there are notable differences between the datasets.

LEED measures the average quarterly earnings paid to full-quarter employees in the construction industry. ${ }^{14}$ Full-quarter earnings can be split into earnings for continuing jobs and new hires. ${ }^{15}$ LEED does not distinguish between part-time and full-time work and does not include hourly wages. In addition, no adjustments are made for the experience and qualification of the employee, and self-employment income is not included in the quarterly statistics.

QES measures the average hourly and weekly paid earnings of those employed in the construction industry. There are no human capital adjustments for those employed. However, the hourly wage measures allow the quantity of labour supplied by an employee to be controlled. 
The LCI measures the changes in labour cost for a job with a specified human capital and specified hours of work, that is, controls for quality and quantity of labour supplied by an employee. ${ }^{16}$ The control for human capital and hours worked makes the LCI better suited to measuring the change in wages for individuals working specified number of hours with similar levels of human capital.

The average earnings growth for those employed in the construction industry as measured by the three datasets is shown in table 1.

\section{Table 1: Percentage Change in Average Earnings as Measured by LEED, QES and LCI, Year to March}

\begin{tabular}{|c|c|c|c|c|c|c|c|}
\hline \multirow[b]{4}{*}{ Quarter } & \multicolumn{3}{|c|}{ Linked Employer Employee Data } & \multicolumn{3}{|c|}{ Quarterly Employment Survey } & $\begin{array}{l}\text { Labour Cost } \\
\text { Index }\end{array}$ \\
\hline & (contro & neither qual & quantity) & \multicolumn{3}{|c|}{ (controls for quantity) } & $\begin{array}{l}\text { (controls for } \\
\text { both quality } \\
\text { and quantity) }\end{array}$ \\
\hline & \multicolumn{3}{|c|}{ Average quarterly earnings, } & \multirow[t]{2}{*}{$\begin{array}{c}\text { Average } \\
\text { weekly paid } \\
\text { earnings }\end{array}$} & \multirow[t]{2}{*}{$\begin{array}{c}\text { Average } \\
\text { weekly paid } \\
\text { earnings FTEs }\end{array}$} & \multirow[t]{2}{*}{$\begin{array}{c}\text { Average } \\
\text { hourly paid } \\
\text { earnings }\end{array}$} & \multirow[t]{2}{*}{$\begin{array}{c}\text { Salaries and } \\
\text { ordinary time } \\
\text { wages (per } \\
\text { hour) }\end{array}$} \\
\hline & All jobs & Continuing & New hires & & & & \\
\hline 2001 & 1.63 & 1.37 & & 2.24 & 1.01 & 4.84 & 1.26 \\
\hline 2002 & 3.44 & 3.48 & 6.45 & 1.27 & 2.20 & -0.06 & 2.22 \\
\hline 2003 & 1.22 & 1.30 & -0.76 & 3.33 & 3.29 & 2.94 & 2.27 \\
\hline
\end{tabular}

Source: Statistics New Zealand, LEED, QES, LCI

All three datasets suggest a positive average earnings growth, indicating a general upward trend in the rate of change of earnings for those employed in the construction industry. However, the degree of growth in average wages and salaries differs by measure and dataset.

\section{Relative wages and salaries}

Year ended March 2001-2006 was also a time when wages and salaries increased across all industries; it was a period of significant employment growth. Hence, it is of interest to observe the increase in average wages and salaries in the construction industry relative to other industries. Relative wages is computed as the ratio of average wages and salaries in the construction industry to all other industries (excluding construction).

\section{Relative earnings as measured by $L E E D$}

Table 2: Relative Average Earnings in the Construction Industry as Measured by LEED, March Quarter

\begin{tabular}{l|c|c|c}
\hline & \multicolumn{3}{|c}{$\begin{array}{c}\text { Relative average quarterly earnings - } \\
\text { full-quarter jobs }\end{array}$} \\
\cline { 2 - 4 } Quarter & All jobs & $\begin{array}{c}\text { Continuing } \\
\text { jobs }\end{array}$ & New hires \\
\hline Mar-01 & 1.07 & 1.05 & 1.24 \\
Mar-02 & 1.06 & 1.04 & 1.21 \\
Mar-03 & 1.05 & 1.03 & 1.20 \\
Mar-04 & 1.05 & 1.03 & 1.21 \\
Mar-05 & 1.05 & 1.03 & 1.23 \\
Mar-06 & 1.06 & 1.04 & 1.21 \\
\hline
\end{tabular}

Source: Statistics New Zealand, LEED
Table 2 shows the relative average earnings ratio measured by LEED. Relative average earnings in the construction industry has consistently been greater than one, suggesting that workers in the industry earned more than workers across all industries during the March year. However, LEED does not control for hours worked; hence, the higher earnings could be related to longer hours worked.

The relatively longer hours of employment by construction workers is evident when looking at the differences between the QES relative average hourly paid earnings and relative average weekly paid earnings (table 4 ); and relative overtime hours paid to construction workers (appendix 2). The overtime analysis (appendix 2) highlights that there was little variation in the overtime hours over the period of interest. Hence, the trend in relative earnings over time is still relevant in investigating a wage response to the heightened demand in the construction industry.

The LEED relative average earnings measures have been stable over the period of interest. Relative average earnings for full-quarter and continuing jobs declined marginally over the period of interest while the relative earnings for new hires increased slightly during the March 2005 year before reverting back to the 2003-2004 ratio of 1.21 during March 2006. Relative average wages by sub-industry as measured by the LEED earnings statistics also suggest a stable pattern in relative wages over time. Therefore, across all individuals in the construction industry receiving wages and salaries as their main income source, there was very little evidence of an increase in average earnings relative to all other industries combined. 
Table 3: Relative Average Earnings as Measured by QES and LCI, March Quarter

\begin{tabular}{l|c|c|c|c}
\hline \multirow{2}{*}{} & \multicolumn{3}{|c|}{ Quarterly Employment Survey } & $\begin{array}{c}\text { Labour Cost } \\
\text { Index }\end{array}$ \\
\cline { 2 - 5 } & $\begin{array}{c}\text { Relative } \\
\text { average } \\
\text { weekly } \\
\text { paid } \\
\text { earnings }\end{array}$ & $\begin{array}{c}\text { Relative } \\
\text { average } \\
\text { weekly paid } \\
\text { earnings } \\
\text { FTEs }\end{array}$ & $\begin{array}{c}\text { Relative } \\
\text { average } \\
\text { hourly } \\
\text { paid } \\
\text { earnings }\end{array}$ & $\begin{array}{c}\text { Relative } \\
\text { salaries and } \\
\text { ordinary } \\
\text { time wages } \\
\text { (per hour) }\end{array}$ \\
Quarter & & & & \\
\hline Mar-01 & 1.19 & 1.03 & 0.92 & 1.00 \\
Mar-02 & 1.15 & 1.00 & 0.90 & 1.00 \\
Mar-03 & 1.13 & 0.99 & 0.89 & 1.00 \\
Mar-04 & 1.11 & 0.97 & 0.88 & 1.00 \\
Mar-05 & 1.14 & 0.99 & 0.89 & 1.02 \\
Mar-06 & 1.13 & 1.00 & 0.88 & 1.02 \\
\hline
\end{tabular}

Source: Statistics New Zealand, QES and LCI

Table 3 shows the relative average earnings as measured by the QES and LCI. The relative earnings as measured by the QES, which controls for the hours worked, suggests that hourly construction earning is lower than total industry. A trend, similar to LEED, is observed in relative earnings over time.

The relative average wage movement in the construction industry as captured by the LCI shows a relatively higher rate of growth in wages and salaries for those with the same level of human capital and who worked a specified number of hours. This provides some evidence to suggest that when the quality (human capital) of labour is controlled, the average wages and salaries in the construction industry increased at a faster rate, that is, was approximately 2 percent higher than all other industries during years 2005 and 2006.

Therefore, when human capital and hours of labour supplied is controlled for, as in the LCI, there is some evidence of an upward movement in relative earnings suggesting a wage (price) response to the heightened demand for construction services. However, at the aggregate level when human capital and hours worked is not controlled, there is very little movement in wages.

The limited average wage response to the surge in demand for construction services is consistent with the findings of Dave Maré and Dean Hyslop (2007). They found that during an economic upswing there is increased hiring of low-skilled and low-paid individuals. Hence, the composition of the workforce shifts toward the lower paid who are often inexperienced, currently out of the labour force or receiving benefit. Given this shift, more weight is attached to the earnings of these workers, which in turn lowers the average mean earnings estimate.

Use of non-pay adjustment mechanisms in adjusting to the higher level of employment is investigated next.

\section{Non-pay adjustments}

Varying the quality or human capital of labour hired is an adjustment response available to employers in addition to wages and salaries. Human capital cannot be easily measured. Experience proxied by age is a commonly used indicator of human capital and is positively related to the level of human capital. The employment of individuals who were formerly receiving a benefit is also used to get an appreciation for changes in human capital of labour hired; unlike experience, it is negatively related to the level of human capital.

A change in the composition of the workforce is investigated by looking at the flows into and out of the construction industry during the period of interest.

\section{Flows into and out of the construction industry}

Simultaneous inflow and outflow of workers is a natural component of a dynamic economy. Flows into the construction industry during a particular year include those receiving wages and salaries or self-employment as their main income source for the first time in the construction industry. The outflow of workers from the construction industry captures those who have received wages and salaries or self-employment income in the construction industry the previous year and not in receipt of earnings in the construction industry in the current year. Table 4 summarises the inflow and outflow of workers into the construction over the six-year period.

Table 4: Flows Into and Out of the Construction Industry $\left({ }^{1)}\right.$, Year to March

\begin{tabular}{c|c|c|c}
\hline Year & Inflows & Outflows & Net Inflows \\
\hline 2001 & 27,430 & 27,300 & 130 \\
2002 & 28,810 & 26,810 & 2,000 \\
2003 & 33,840 & 25,160 & 8,680 \\
2004 & 37,790 & 25,690 & 12,100 \\
2005 & 43,760 & 28,160 & 15,600 \\
2006 & 45,110 & 32,760 & 12,350 \\
\hline
\end{tabular}

Source: Statistics New Zealand, LEED

(1) The flow statistics have been randomly rounded to base 10.

Over the 2001-2006 years, the number of individuals moving out of the construction industry decreased from 27,310 in 2001 to 25,160 in 2003 , after which it progressively increased. The age profile of those moving out of the construction industry (see appendix 3 ) suggests that the relative proportion of individuals from different age groups exiting the construction industry was largely unchanged over the years. Hence, similar types of individuals, measured in terms of age, continued to flow out of the construction industry.

The employment growth in the construction industry was largely driven by the increased inflow of workers relative to total outflows. During the 2001 March year, there was one inflow for every outflow. This increased to 1.6 inflows for every outflow in 2005 before decreasing to 
1.4 in 2006. The Inflow of workers into the construction industry can be further distinguished by:

Flows from alternative industries capture those receiving wages and salaries or self-employment income as their main income source in an industry other than construction in the previous year.

- Flows from income-tested benefits include those receiving an income-tested main benefit as their main income source the previous year. ${ }^{17}$
Finally, flows from out of the labour force status captures those out of the tax system, for example students, migrants and those undertaking caring responsibilities; and also those receiving one of Accident Compensation Corporation (ACC), pension, paid parental leave or student allowance as their main income source the previous year.

The flow of individuals into the construction industry from the above three conditions is shown in table 5 .

Table 5: Flows Into the Construction Industry ${ }^{(1)}$, Year to March

\begin{tabular}{c|c|c|c|c}
\hline Year & $\begin{array}{c}\text { Alternative } \\
\text { industry }\end{array}$ & Benefit & $\begin{array}{c}\text { Out of } \\
\text { workforce }\end{array}$ & $\begin{array}{c}\text { Total } \\
\text { inflow }\end{array}$ \\
\hline \multicolumn{5}{c}{ Inflows (number) } \\
2001 & 17,010 & 3,930 & 6,490 & 27,430 \\
2002 & 17,610 & 3,790 & 7,410 & 28,810 \\
2003 & 20,620 & 4,160 & 9,060 & 33,840 \\
2004 & 22,980 & 4,290 & 10,510 & 37,780 \\
2005 & 26,860 & 4,670 & 12,210 & 43,750 \\
2006 & 28,450 & 3,400 & 13,260 & 45,110 \\
\hline
\end{tabular}

\begin{tabular}{c|c|c}
\hline $\begin{array}{c}\text { Alternative } \\
\text { industry }\end{array}$ & Benefit & $\begin{array}{c}\text { Out of } \\
\text { workforce }\end{array}$ \\
\hline \multicolumn{3}{|c}{ Inflows (\%) } \\
62.0 & 14.3 & 23.7 \\
61.1 & 13.2 & 25.7 \\
60.9 & 12.3 & 26.8 \\
60.8 & 11.3 & 27.8 \\
61.4 & 10.7 & 27.9 \\
63.1 & 7.5 & 29.4 \\
\hline
\end{tabular}

Source: Statistics New Zealand, LEED

(1) The inflow statistics have been randomly rounded to base 10 .

The inflow of workers into the construction industry over the 2001-2006 period were predominantly from other industries, with at least six out of every ten individuals engaged in an alternative industry the previous year. The share of total inflows previously in receipt of income from benefit declined over the years. On the other hand, there was an increased reliance on inflows from out-ofthe-workforce status with the relative proportion increasing from 23.7 percent in 2001 to 29.4 percent in 2006. The inflow from the three sources is explored next.

\section{Inflows from alternative industries}

The relocation of workers within and across industries is a natural component of a dynamic economy. Technological changes and demand shifts enhance interand intra-industry reallocations. Given the heightened demand in the construction industry, the inflow of workers from alternative industries can be expected, to take advantage of the relatively higher returns. Table 6 summarises the inflow of workers into construction by source industry over the 2001-2006 period.

Table 6: Inflows into Construction by Source Industry, Year to March

\begin{tabular}{|c|c|c|c|c|c|c|}
\hline \multirow[b]{3}{*}{ Industry } & \multicolumn{6}{|c|}{ Year } \\
\hline & 2001 & 2002 & 2003 & 2004 & 2005 & 2006 \\
\hline & \multicolumn{6}{|c|}{$\%$} \\
\hline Agriculture, forestry and fishing & 9.7 & 11.0 & 11.5 & 11.7 & 12.0 & 11.0 \\
\hline Mining & 1.1 & 0.8 & 0.8 & 0.8 & 0.8 & 0.7 \\
\hline Manufacturing & 19.8 & 18.5 & 18.9 & 19.6 & 20.3 & 19.5 \\
\hline Electricity, gas and water supply & 1.8 & 2.1 & 2.3 & 0.5 & 0.4 & 0.6 \\
\hline Wholesale trade & 8.1 & 7.5 & 7.3 & 8.2 & 7.5 & 7.7 \\
\hline Retail trade & 12.3 & 12.6 & 12.3 & 13.4 & 13.2 & 12.9 \\
\hline Accommodation, cafes and restaurants & 4.2 & 4.4 & 5.3 & 5.1 & 5.0 & 4.9 \\
\hline Transport and storage & 4.6 & 5.4 & 5.7 & 4.8 & 5.2 & 4.9 \\
\hline Communication services & 3.8 & 2.3 & 1.6 & 1.3 & 1.2 & 1.1 \\
\hline Finance and insurance & 1.4 & 1.3 & 0.9 & 1.1 & 0.9 & 1.0 \\
\hline Property and business services & 17.9 & 19.2 & 18.1 & 19.8 & 19.6 & 21.6 \\
\hline Government administration and defence & 2.1 & 1.7 & 1.9 & 1.4 & 1.3 & 1.4 \\
\hline Education & 2.3 & 2.4 & 2.5 & 2.7 & 2.7 & 2.5 \\
\hline Health and community services & 2.5 & 2.2 & 2.2 & 2.4 & 2.2 & 2.2 \\
\hline Cultural and recreational services & 2.4 & 2.6 & 2.9 & 2.1 & 2.2 & 2.7 \\
\hline Personal and other services & 3.4 & 2.9 & 2.9 & 3.1 & 3.4 & 3.4 \\
\hline Not elsewhere classified & 2.7 & 3.1 & 2.7 & 2.1 & 2.2 & 2.0 \\
\hline All industries ${ }^{(1)}$ & 17,010 & 17,610 & 20,620 & 22,980 & 26,860 & 28,450 \\
\hline
\end{tabular}

Source: Statistics New Zealand, LEED

(1) The inflow statistics have been randomly rounded to base 10. 
Inflows from other industries accounted for the largest proportion of total inflows. In 2001, over half (52 percent) of the total inflows into construction from other industries came from manufacturing (19.8 percent), property and business services (17.9 percent) and retail trade ( 12.3 percent). These were the top three industries in terms of filled jobs hence, the relatively large share of inflows from these industries is a reflection of their size.

The relative contribution of these industries towards total inflows from other industries increased marginally to 54 percent. The relative contribution of all other industries towards total inflows was largely unchanged. This suggests that following the heightened demand for construction services the construction industry continued to source its workers from the same industries. However, the type of workers flowing from these industries into the construction industry shifted towards younger hence, less experienced individuals. Table 7 summarises the age profile of those entering the construction industry from other industries in 2001 and 2006.

Table 7: Inflows From Other Industries into Construction by Age, Year to March

\begin{tabular}{|c|c|c|c|c|}
\hline \multirow{2}{*}{$\begin{array}{l}\text { Age } \\
\text { group }\end{array}$} & \multicolumn{4}{|c|}{ Industry } \\
\hline & Manufacturing & Retail trade & $\begin{array}{c}\text { Property and } \\
\text { business services }\end{array}$ & Total industry \\
\hline & & $2001(\%)$ & & \\
\hline $15-19$ & 13.5 & 39 & 9.8 & 16.9 \\
\hline $20-24$ & 13.4 & 13.9 & 11.4 & 12.2 \\
\hline $25-29$ & 14.5 & 10.4 & 14.1 & 13.1 \\
\hline $30-34$ & 15.2 & 9.8 & 15.7 & 14 \\
\hline $35-39$ & 13.1 & 7.6 & 14.1 & 13.1 \\
\hline $40-44$ & 11.5 & 7.1 & 11.4 & 11 \\
\hline $45-49$ & 7.7 & 5.4 & 10 & 8.3 \\
\hline $50-54$ & 6.1 & 4 & 7 & 6.3 \\
\hline $55-59$ & 3.9 & 2.1 & 4.2 & 3.5 \\
\hline $60-64$ & 1 & 0.7 & 1.9 & 1.4 \\
\hline \multirow[t]{2}{*}{$65+$} & 0.2 & 0.1 & 0.3 & 0.2 \\
\hline & & $2006(\%)$ & & \\
\hline $15-19$ & 19.3 & 39.7 & 15.5 & 21.7 \\
\hline $20-24$ & 16.4 & 13.7 & 14.2 & 14.5 \\
\hline $25-29$ & 12.5 & 9.1 & 11.5 & 11.1 \\
\hline $30-34$ & 12.6 & 9.5 & 12.4 & 12 \\
\hline $35-39$ & 11.6 & 8 & 12.3 & 11.3 \\
\hline $40-44$ & 10 & 6.5 & 10.9 & 9.8 \\
\hline $45-49$ & 7.4 & 5.3 & 9.1 & 7.9 \\
\hline $50-54$ & 5.5 & 3.9 & 6.7 & 5.8 \\
\hline $55-59$ & 3.2 & 2.9 & 5 & 3.9 \\
\hline $60-64$ & 1.4 & 1.3 & 1.9 & 1.6 \\
\hline $65+$ & 0.3 & 0.2 & 0.5 & 0.4 \\
\hline
\end{tabular}

Source: Statistics New Zealand, LEED

The significant driver of the increased inflow from other industries was from those aged 15 to 24 years. The relative proportion of 15 - to 24 -year olds entering the construction industry from all other industries increased from 29.1 percent in 2001 to 36.2 percent in 2006. Hence, despite continuing to source its workers from the same industries, there were concessions on the quality or human capital of workers flowing from these industries towards younger and less experienced individuals.

\section{Inflows from benefit}

Although benefit recipients are not homogenous, the group has distinctive characteristics that place them at a disadvantage in the labour market. Most have limited educational attainment and limited work experience, hence, have lower levels of human capital.
The number of former benefit recipients entering the construction industry increased from 3,789 in 2002 to 4,670 in 2005 , before decreasing to 3,400 in 2006 . There was a reduced reliance on the inflow of former benefit recipients as indicated by the reduced proportion of total inflows, decreasing from 14.3 percent in 2001 to 7.5 percent in 2006. However, the reduced reliance can be partly attributed to the smaller number of people on benefit during this period of strong employment growth (see table 8). The number of individuals receiving income from benefit as their main income source decreased by 19.9 percent in the six years from 2001 to 2006; this is expected to have reduced the population of beneficiaries that can be drawn on for employment in the construction industry. 
Table 8: Total Number of Individuals Receiving Benefit as Their Main Income, March Year

\begin{tabular}{lc}
\hline Year & Number of individuals \\
\hline 2001 & 411,140 \\
2002 & 399,640 \\
2003 & 386,080 \\
2004 & 371,310 \\
2005 & 348,410 \\
2006 & 329,490 \\
\hline
\end{tabular}

Source: Statistics New Zealand, LEED

(1) The inflow statistics have been randomly rounded to base 10 .

\section{Inflow from out of the workforce}

Over the 2001 to 2006 period there was increased reliance on workers who were out of the workforce the previous year. The proportion of total inflows from this group increased from 23.7 percent in 2001 to 29.4 percent in 2006. Individuals who were previously out of the workforce includes those out of the tax system such as students, migrants and those undertaking caring responsibilities; and those receiving one of ACC, government superannuation, paid parental leave or student allowance as their main income source the previous year. The majority of flows form out-ofworkforce status (over 80 percent) is accounted by flows from out the tax system.

The number of individuals flowing into the construction industry from out-of-workforce status increased across all age groups in the six years. Table 9 summarises this inflow according to age group.

Table 9: Inflows into Construction from Out-ofworkforce Status, by Age, Year to March

\begin{tabular}{|c|c|c|c|c|c|c|}
\hline \multirow{3}{*}{$\begin{array}{c}\text { Age } \\
\text { group } \\
\text { (years) }\end{array}$} & \multicolumn{6}{|c|}{ Year } \\
\hline & 2001 & 2002 & 2003 & 2004 & 2005 & 2006 \\
\hline & \multicolumn{6}{|c|}{$\%$} \\
\hline $15-19$ & 28.4 & 26.9 & 26.1 & 26.7 & 26.6 & 24.1 \\
\hline $20-24$ & 9.7 & 10.2 & 9.8 & 10.3 & 11 & 10.7 \\
\hline $25-29$ & 13.6 & 14.3 & 14.8 & 13.9 & 13 & 13.3 \\
\hline $30-34$ & 12.2 & 12.1 & 12.5 & 13.4 & 12.6 & 12.2 \\
\hline $35-39$ & 11 & 9.8 & 11.2 & 10.4 & 10.6 & 11.5 \\
\hline $40-44$ & 8.5 & 9.3 & 8.6 & 8.8 & 9.1 & 9.4 \\
\hline $45-49$ & 6 & 6 & 5.8 & 6.4 & 6.2 & 6.7 \\
\hline $50-54$ & 4.3 & 4.7 & 4.4 & 4.2 & 4.1 & 4.6 \\
\hline $55-59$ & 2.8 & 2.6 & 3.1 & 2.5 & 3.1 & 3.4 \\
\hline $60-64$ & 1.7 & 1.6 & 1.7 & 1.7 & 1.6 & 1.9 \\
\hline $65+$ & 1.8 & 2.4 & 2.1 & 1.8 & 2.2 & 2.2 \\
\hline $\begin{array}{l}\text { Total } \\
\text { Age }^{(1)}\end{array}$ & 6490 & 7410 & 9060 & 10510 & 12210 & 13260 \\
\hline
\end{tabular}

Source: Statistics New Zealand, LEED

(1) The inflow statistics have been randomly rounded to base 10 .

The 15- to 19-year age group consistently accounted for the majority of inflows from out-of-workforce status, capturing the move from study to employment. Over the years the relative share of total inflows from this group decreased while the relative share of most other age groups increased, particularly those from the 35 years and over age group. As noted above, the inflows from those out of the workforce captures a range of individuals with varying backgrounds hence, varying levels of human capital. However, using age as a proxy for experience, increased employment of relatively older workers suggests that quality or human capital was not compromised in hiring increased numbers of workers from out of the workforce.

During the period of heightened demand there was an increased entry of self-employed individuals into the construction industry. This is considered next.

\section{Entry of self-employed individuals}

Traditionally, the construction industry has had one of the highest rates of self-employment. Self-employed individuals can be seen as suppliers of labour, since they absorb some of the demand for construction services. If they employ other workers they have an influence on labour demand.

There are two schools of thought on the determinants of self-employment. The 'recession push' theory assumes that self-employed individuals are pushed into establishing their own ventures because they cannot find suitable paid employment opportunities. Under this theory, self-employment is negatively related to economic activity. The alternative school of thought is referred to as the 'entrepreneurial pull' theory. Under this view, entrepreneurs are individuals with special abilities and self-knowledge of this ability motivates them to engage in risk-taking entrepreneurial pursuits. Hence, favourable macroeconomic conditions would offer an increased incentive to undertake these risk-taking activities. There is empirical evidence to suggest both hypotheses.

The number of individuals who received selfemployment income as their main source of income increased by 23.5 percent in the construction industry; the corresponding increase in total industry was only 0.06 percent. The increase in self-employment during a time of increased economic activity and low unemployment lends some weight to the pull theory of self-employment.

Table 10: Entry into Self-employment in the Construction Industry and Total Industry ${ }^{(1)}$, Year to March

\begin{tabular}{c|c|c|c}
\hline Year & Construction & $\begin{array}{c}\text { Total industry } \\
\text { (all industries } \\
\text { minus } \\
\text { construction) }\end{array}$ & $\begin{array}{c}\text { Flows into } \\
\text { construction } \\
\text { relative to flows } \\
\text { across all other } \\
\text { industries }\end{array}$ \\
\hline 2001 & 9,370 & 50,860 & 0.18 \\
2002 & 9,250 & 48,850 & 0.19 \\
2003 & 10,850 & 52,390 & 0.21 \\
2004 & 12,410 & 52,670 & 0.24 \\
2005 & 13,680 & 55,750 & 0.25 \\
2006 & 13,450 & 54,390 & 0.25 \\
\hline
\end{tabular}

Source: Statistics New Zealand-LEED

(1) Figures have been randomly rounded to the nearest 10 . 
Over 2001-2006 there was an increased flow of individuals moving into self-employment in the construction industry and across all other industries combined, reflecting the buoyant economic conditions for entrepreneurial ventures. The share of self-employed individuals entering construction relative to all other industries increased over the years from 18 percent to 25 percent. In addition to increasing the level of employment, this is also expected to relieve some of the demand pressures for construction services.

\section{Summary}

The analysis has showed that employment growth in the construction industry was largely driven by the increased inflow of both the self-employed as well as individuals receiving wages and salaries, relative to total outflows.

There was an increased reliance on workers from out of the workforce. Three out of every 10 workers entering the construction industry in 2006 were accounted for by those previously out of the workforce. The 35 years and over age group represented an increasing share of inflow from this source. During this period there was a reduced dependence on former benefit recipients. The flows by those formerly receiving a benefit as their main income source decreased over the years. This is likely to have been caused by fewer people on benefit and hence, fewer people that can be drawn on for employment in the construction industry. The positive human capital effects from hiring older workers and fewer former benefit recipients appears to have been offset by the increased inflow of younger workers from other industries.

The largest share of inflow into the construction industry continued to be those from other industries, with every six in ten workers entering from engagement in an alternative industry the previous year. The relative proportion of individuals entering the construction industry from other industries was largely unchanged; however, the composition of workers flowing from alternative industries into construction shifted towards younger and hence. less experienced workers. This suggests that in adjusting to the higher level of employment, the quality of workers was compromised.

The trend for employing younger workers could be viewed as a response to the industry training programmes where employers hire young apprentices. However, taking on an apprentice is not without cost to the employer. Hence, it is a calculated response to market conditions.

Assuming that wages paid is related to the productivity of the worker which in turn is related to the human capital of the worker, the increased entry of younger and less experienced workers partly explains the subdued wage response to the heightened demand. In addition to changes in the composition of human capital, the increased entry of self-employed individuals into the industry might also explain the subdued wage response.

\section{Conclusion}

The heightened demand for construction services was brought about by the low interest rates, high population growth, strong wage and job growth and property investments from overseas. Following this, there was a related increase in employment. This paper sought to investigate how the market adjusted to the higher level of employment.

In adjusting to the higher levels of employment, the use of wages as an adjustment response was limited. The LCI, which controls for the human capital and number of hours worked, suggested that wages and salaries in the construction industry increased at a faster rate than total industry, for individuals who worked a specified number of hours with the specified levels of human capital. Across the industry, the relative average wage growth was subdued.

This is explained by the change in the composition of human capital of those employed in the industry. Human capital was measured by experience using age as a proxy, and the degree to which former benefit recipients were hired. There was an increased reliance on workers from out of the workforce. Three out of every 10 workers entering the construction industry in 2006 were accounted for by those previously out of the workforce. The 35 years and over age group represented an increasing share of inflow from this source. The flows by those formerly receiving a benefit as their main income source decreased over the years. This is likely to have been caused by fewer people on benefit and hence, fewer people that can be drawn on for employment in the construction industry. The positive human capital effects from hiring older workers and fewer former benefit recipients appears to have been offset by the increased inflow of younger workers from other industries.

The largest share of inflow into the construction industry continued to be from other industries, with every six in ten workers entering the construction industry from engagement in an alternative industry the previous year. The construction industry continued to source its workers from the same industries; however, the composition of workers flowing from alternative industries into construction shifted towards younger and hence, less experienced workers. This suggested that in adjusting to the higher level of employment, the quality of workers was compromised.

A positive trend in the entry of self-employed is also observed over time. Increased entry of self -employed individuals together with the increased employment of younger and less experienced individuals is expected to have reduced the wage pressures on the industry as a whole, at a time of strong employment growth. 


\section{Future research}

A shift in the composition of the workforce towards younger and less experienced workers has implications for the industry productivity. Hence, it is of interest to investigate changes in industry productivity during this time of increased employment. Additionally, with the recent downturn in construction activity, it is of interest to investigate how the market has responded.

\section{Notes}

1. Department of Labour. (2004). Construction Industry, Workforce Trends. Department of Labour. http://www.dol.govt.nz/PDFs/workinsight-issue-5-ch12.pdf [accessed 20 August 2007].

2. Statistics New Zealand. (2007). LEED Annual Statistics. Statistics New Zealand. http://www.stats.govt.nz/products-andservices/table-builder/leed-annual-tables.htm [accessed 10 September 2007]

3. Maré, D. and Hyslop, D. (2006). Worker firm heterogeneity and matching: an analysis using worker and firm fixed effects estimation from $L E E D$. Statistics New Zealand. Wellington.

4. See Appendix 1 for detailed description of subgroups and classes within the construction industry.

5. Statistics New Zealand. (2007). National accounts (Revised) year ended March 2007. Statistics New Zealand. http://www.stats.govt.nz/products-andservices/hot-off-the-press/nationalaccounts/national-accounts-revised-year-endedmarch-07-hotp.htm?page=para004Master [accessed 10 September 2007].

6. Statistics New Zealand. (2007). LEED Annual Statistics. Statistics New Zealand. http://www.stats.govt.nz/products-andservices/table-builder/leed-annual-tables.htm [accessed 10 September 2007]

7. Statistics New Zealand. (2007). LEED Annual Statistics. Statistics New Zealand. http://www.stats.govt.nz/products-andservices/table-builder/leed-annual-tables.htm [accessed 10 September 2007]

8. Department of Building and Housing. (2005). Building Practitioner Licensing: Background information on occupations that may be covered by occupational licensing. Department of Building and Housing .http://www.dbh.govt.nz/UserFiles/File/Building/o ccupational-licensing/bpl-background.pdf. [accessed 23 August 2007].
9. The Building Act of 2004 seeks to change this practice though The Licensed Building Practitioner Scheme to be implemented in 2009. The sheme will give competent carpenters, builders, site supervisors, designers and some specialist trades formal endorsement. In addtion, requires all building and design work to be carried out or supervised by a licensed building practitioners. To become licensed, practitioners will have to show a certain level of capability based on practical experience and/or qualifications.

10. Department of Labour. (2006). Union Membership Return 2005. Department of Labour, http://www.ers.dol.govt.nz/union/pdfs/UnionMembership-2006.pdf [accessed 1 May 2008).

11. Department of Labour. (2007). Occupation shortages in New Zealand. Department of Labour. http://www.dol.govt.nz/publications/jvm/shortage 2006/shortage2006_09.asp [accessed 20 August 2007].

12. Statistics New Zealand. (2007). LEED Annual Statistics. Statistics New Zealand. http://www.stats.govt.nz/products-andservices/table-builder/leed-annual-tables.htm [accessed 10 September 2007].

13. The higher cost of labour might also trigger a substitution response where other factors of production such as capital are substituted for labour.

14. Full-quarter employees are employees who were employed continually through the quarter by the same employer.

15. An employee has a continuing job if they have been with the same employer continuously over the current and previous quarter. A new hire is an employee who has been with the same employer continuously for the current quarter but began the job sometime in the previous quarter. New hires must not have been employed with the same employer in the 12 months prior to the job start date. As a result, seasonal staff and employees who have been rehired within this time period are excluded from new hires.

16. The reweighted LCI linked at December 2001 to the previous series is used in this study.

17. Benefit includes all taxable income tested benefits ie Unemployment Benefit, Domestic Purposes Benefit, Sickness Benefit, Invalid's Benefit and Widows benefit and emergency benefit.

18. One caveat with this proxy is that individuals can work more hours than what they are actually paid 
for, hence the hours paid often underestimates the true hours worked.

\section{References}

Blandy, R. and Richardson, S. (1982). How Labour Markets Work: Case Studies in Adjustment. Longman Cheshire.

Building and Construction Industry Training Organisation. (2007). Modern Apprenticeships, Building and Construction Industry Training Organisation.

http://www.bcito.org.nz/qualifications/modernapprenticeships.html [accessed 21 August 2007].

Department of Building and Housing. (2005). Building Practitioner Licensing: Background information on occupations that may be covered by occupational licensing. http:/www.dbh.govt.nz/UserFiles/File/Building/o ccupational-licensing/bpl-background.pdf [accessed 23 August 2007].

Department of Labour. (2004). Construction Industry, Workforce Trends. Department of Labour. http://www.dol.govt.nz/PDFs/work-insight-issue5-ch 12.pdf [accessed 20 August 2007].

Department of Labour. (2007). Occupation shortages in New Zealand. Department of Labour. http://www.dol.govt.nz/publications/jvm/shortage 2006/shortage2006_09.asp [accessed 20 August 2007].

Maré, D. and Hyslop, D. (2008). Cyclical Earnings Variation and the Composition of Employment. Statistics New Zealand. Wellington.

Maré, D. and Hyslop, D. (2006). Worker firm heterogeneity and matching: an analysis using worker and firm fixed effects estimation from $L E E D$. Statistics New Zealand. Wellington.

\author{
Author \\ Menaka Saravanaperumal \\ Work Knowledge and Skills \\ Statistics New Zealand \\ Statistics House \\ The Boulevard \\ Harbour Quays \\ PO Box 2922 \\ Wellington 6140 \\ Menaka.Saravanaperumal@stats.govt.nz
}

\section{Appendix 1}

Australian and New Zealand Standard Industrial Classification (ANZSIC96) - Construction Industry

\begin{tabular}{l} 
Construction \\
\hline General construction \\
\hline Building construction \\
House construction \\
Non-residential building construction \\
Residential building construction nec \\
Non-building construction \\
Non-building construction nec \\
Road and bridge construction \\
\hline Construction trade services \\
\hline Site preparation services \\
Site preparation services \\
Building structure services \\
Bricklaying services \\
Concreting services \\
Roofing services \\
Structural steel erection services \\
Installation trade services \\
Air conditioning and heating services \\
Electrical services \\
Fire and security system services \\
Plumbing services \\
Building completion services \\
Carpentry services \\
Glazing services \\
Painting and decorating services \\
Plastering and ceiling services \\
Tiling and carpeting services \\
Construction services nec \\
\hline
\end{tabular}

\section{Appendix 2}

\section{Hours paid}

Hours paid, as measured by the Quarterly Employment Survey (QES), is used as a proxy for hours worked. ${ }^{18}$.

QES reports on the weekly hours paid to ordinary, fulltime and all full-time or equivalent employees and all employees. A full-time or equivalent employee (FTE) is defined as the number of full-time employees (employees working more than 30 hours per week) and half the number of part-time employees (number of employees working less than 30 hours per week). 'All employees' is the total of full- and part-time employees.

Weekly hours paid to individuals in the construction industry, relative to all industries excluding construction, is used to gauge the extent of the increase in hours worked in the construction industry relative to total industry. 
Appendix Table 1: Relative Hours Paid in the Construction Industry ${ }^{(1)}$,March Quarter

\begin{tabular}{c|c|c|c}
\hline Quarter & $\begin{array}{c}\text { Ordinary } \\
\text { hours }^{(2)}\end{array}$ & $\begin{array}{c}\text { Overtime } \\
\text { hours }^{(3)}\end{array}$ & $\begin{array}{c}\text { Total hours } \\
\text { (ordinary hours } \\
\text { and overtime } \\
\text { hours) }\end{array}$ \\
\hline \multicolumn{4}{c}{ All employees } \\
Mar 2001 & 1.26 & 2.17 & 1.28 \\
Mar 2002 & 1.24 & 2.58 & 1.28 \\
Mar 2003 & 1.23 & 2.49 & 1.27 \\
Mar 2004 & 1.22 & 2.15 & 1.24 \\
Mar 2005 & 1.25 & 2.30 & 1.28 \\
Mar 2006 & 1.24 & 2.61 & 1.28 \\
\hline
\end{tabular}

\section{Full-time equivalent employees (FTEs)}

\begin{tabular}{llll} 
Mar 2001 & 1.08 & 1.86 & 1.10 \\
Mar 2002 & 1.09 & 2.25 & 1.12 \\
Mar 2003 & 1.08 & 2.19 & 1.11 \\
Mar 2004 & 1.07 & 1.89 & 1.09 \\
Mar 2005 & 1.09 & 2.01 & 1.12 \\
Mar 2006 & 1.09 & 2.32 & 1.12 \\
\hline
\end{tabular}

Source: Statistics New Zealand - QES

(1) Number of hours paid in the construction industry relative to all industries excluding construction.

(2) The number of weekly paid hours to which the ordinary time payout relates. Paid travelling time, sick pay, holiday pay and other temporary absences are included.

(3) The number of weekly paid hours to which the overtime payout relates.

All employee and FTE paid hours in the construction industry is consistently higher than the paid hours for all industries as indicated by the above one ratio. This is particularly noticeable in the relative overtime hours where both 'all employees' and' FTEs' in the construction industry have consistently worked twice the overtime hours as all employees and FTE across all industries.

The higher relative ordinary time paid hours for 'all employees' compared with 'FTE' employees suggests that part-time workers in the construction industry work relatively longer hours than those across all industries and there are fewer part-time individuals in the construction industry than across all industries.

The relative hours paid data does not suggest that employers varied the hours worked by employees. Given the above average overtime hours paid in the construction industry relative to all other industries, the use of overtime as an adjustment mechanism might be limited.

\section{Appendix 3}

The age profile of those flowing out of the construction industry during the six-year period is shown in appendix table 2 .

\section{Appendix Table 2: Outflows from Construction by age, Year to March}

\begin{tabular}{c|c|c|c|c|c|c}
\hline \multirow{2}{*}{$\begin{array}{c}\text { Age } \\
\text { group } \\
\text { (years) }\end{array}$} & \multicolumn{6}{|c}{ Year } \\
\cline { 2 - 7 } & 2001 & 2002 & 2003 & 2004 & 2005 & 2006 \\
\cline { 2 - 7 } & \multicolumn{6}{|c}{$\%$} \\
\hline $15-19$ & 9.3 & 9.0 & 9.3 & 9.9 & 10.3 & 11.0 \\
$20-24$ & 15.0 & 14.2 & 14.0 & 14.3 & 14.4 & 15.3 \\
$25-29$ & 14.4 & 14.0 & 12.7 & 12.2 & 11.7 & 12.1 \\
$30-34$ & 13.6 & 14.4 & 13.2 & 12.9 & 12.9 & 12.1 \\
$35-39$ & 13.1 & 12.9 & 13.1 & 12.7 & 12.6 & 12.1 \\
$40-44$ & 11.1 & 11.3 & 11.5 & 11.4 & 11.4 & 11.0 \\
$45-49$ & 8.1 & 8.7 & 8.6 & 8.6 & 9.6 & 8.8 \\
$50-54$ & 6.5 & 6.4 & 7.1 & 7.0 & 6.4 & 6.6 \\
$55-59$ & 4.4 & 4.3 & 4.8 & 5.0 & 4.9 & 4.9 \\
$60-64$ & 3.1 & 3.4 & 3.8 & 3.6 & 3.4 & 3.5 \\
$65+$ & 1.3 & 1.5 & 2.1 & 2.3 & 2.4 & 2.7 \\
& & & & & & \\
Total & & & & & & \\
Age ${ }^{(1)}$ & 27,310 & 26,810 & 25,160 & 25,690 & 28,160 & 32,750 \\
\hline
\end{tabular}

Source: Statistics New Zealand, LEED

(1) Figures have been randomly rounded to the nearest 10 . 